\title{
INVESTIGATING TEACHING SPEAKING SKILLS THROUGH A.V.AIDS FOR ESL LEARNERS
}

\author{
Prof. Muhammad Safdar Bhatti ${ }^{\star}$, Rafia Mukhtar ${ }^{2}$, Aisha Arshad $^{3}$, Zahida Jabeen ${ }^{4}$ \\ ${ }^{1}$ TEFL Coordinator, AIOU, Bahawalpur-Pakistan Safdarbhatti2001@gmail.com \\ 2Director, SAQE, Bahawalpur-Pakistan Saqe1994@gmail.com \\ ${ }^{3}$ Instructor, SAQE, Bahawalpur-Pakistan Humayun.aisha@yahoo.com \\ ${ }^{4}$ Instructor, SAQE, Bahawalpur-Pakistanzahidajabeen6@gmail.com \\ ${ }^{*}$ Corresponding Author
}

\begin{abstract}
The quality of our expression depends on our use of speaking skills. The importance and value of speaking English has been accepted worldwide. English language is most dynamic and crucial aspect of universal human interaction. In Pakistan, teaching of English was mainly focused upon reading and writing skills. But in today's world, listening and speaking skills have become much more important than in the past. Present study is an investigation in the field of teaching speaking skills through A.V. Aids. It is said that now the trends have been changed and teachers are getting acknowledged with the importance of speaking skills. Recently, AV. aids are being used frequently in the classrooms to make the teaching learning process easy, attractive and interesting. At the same time when trends are changing on daily basis, there are some Govt. institutes which are still following the traditional methods of teaching speaking skills. In Pakistani scenario, the situation is alarming. Govt. institutes are still following the traditional ways of teaching. So in the present study, the focus is on this matter whether the use of A.V. Aids can be beneficial in bringing a positive change in the teaching learning process of speaking skills for the ESL learners. So the current study investigates the use of A.V. Aids in classrooms and its drastic effects on teaching speaking skills to the teen aging ESL learners. The collective problems of teacher and the students during speaking skills was the main focus of the study. It was a pre-test post-test experimental design. Fifty students participated in this study. Sample of the study were teen aging ESL learners. Observation and questionnaire were used as a tool to collect data from respondents. There was a significant difference between pre-test and post-test results. It was suggested that speech practice training with the help of AV aids should encouraged at secondary level.
\end{abstract}

Keywords: Language, Speaking Skills, A.V. Aids, Listening Skills and Investigation. 


\section{INTRODUCTION}

English is the craze of upcoming and up growing generation. The role of audio-visuals is unavoidable for better learning (Swank, 2011). The students find it easier to study with audio-visuals to make the process of learning meaningful and stress-free education (Ameh, 2012). There is a positive effect of audios and video use on students' participation and motivation. They are the basic characteristics of mastering the language (Seçera, Sahin, \& Alci, 2015). Human beings need a language to communicate with the people of the world. For this purpose, there is a dire need of a language of international level. Obviously, English has won this status and has become a source of communication among the people of different parts of the world. There are number of factors that are responsible for poor English speaking proficiency. They are shyness, making joke by fellows, viva voce exams (Dalkılıç, 2013; Park \& Lee, 2005).

It is fulfilled only if the teachers provide more activities and situations for strengthening their speaking competence through AV aids. The competence and confidence in speaking may be developed from appropriate helping aids, designed syllabus, teaching methods, and ample training practices (Bailey, 2005; Songsiri, 2007). One possible reason of low speaking proficiency is the result of limited access to audio videos aids and authentic materials(Bal-Gezegin, 2014).Most of the English language learners feel speaking difficulty in public, oral communication, low vocabulary, pronunciation errors, lack of grammatical familiarity (Wörde, 2003; Woodrow, 2006).

The students at secondary level are aware of English language importance during academic years because it is compulsory from class one and 45 minutes period is allocated daily for its teaching. The competency level of Pakistani pupils in English is very poor. It is a bitter fact that our students consider that English is a difficult language. Actually it is not difficult if it is taught in an easy way. If the interest of the learners is created, it will not be difficult at all. Comprehensive speaking skills are necessary for effective communication in language learning especially when mother tongue is not used (Boonkit, 2010). Effective speaking creates abundance of benefits for students. It received high level of appreciation during traditional speaking events, job training process and interviews (Osborn, Osborn, \& Osborn, 2008).

\subsection{Objectives of the Study}

Following were the objectives of the study:

1. To improve speaking skills of ESL learners.

2. To use A. V. aids in an English language class.

3. To explore how A. V. aids can enhance speaking skills of ESL learners.

\subsection{Research Hypotheses}

The following hypotheses were made for the study:

Ho1: There is no apparent distinction between pre-test and posttest ESL learners' performance.

Ho2: There is no apparent distinction between AV aids usage and learning satisfaction.

Ho3: There is no significant correlation between AV aids usage and learning satisfaction.

\subsection{Delimitations of the Study}

1. The study was limited to investigate speaking skills of ESL learners.

2. Students of secondary level were selected for the study.

3. Students of public sector schools of Bahawalpur were part of this study.

\section{REVIEW OF RELATED LITERATURE}

Teen aging is a pretty suitable age for learning a language to speak. This task can be improved by practice if the learners are given different activities to be helpful in improving their speaking skills. Actually ESL learners give more time to text books. Teachers as well as students do not feel any need to get command over speaking skills. No activity is given to the students which may prove helpful to improve their speaking skills. The students listen to the lecture of the teacher which is often in Urdu, their native language. In this way, they cannot get command 
over speaking skills. According to Zaremba (2006), speech skills are concerned with work experience, academic credentials, motivation, and recruitment for employees. English as a foreign language students have fewer chances to speak English outside the classroom. The use of AV aids helps them to interact with international community (Zhang, 2009).

The non-native effect, teachers' interruption, and low level of English proficiency as well as low self-confidence may be improved by additional exercises with the help of AV aids (Ohata, 2005; Awan et al., 2010). If the learners want to get command over speaking skill, they can use authentic material with the help of $A$. V. aids. Linguists suggest that if a learner wants to learn a foreign language, it is necessary for him to listen to that language attentively and then try to speak in that language. He can use that language according to different situations. Bailey (2005) and Goh (2007) enlisted to develop of speaking proficiency by means of structural design, teaching principles, use of appropriate materials, and assessment. Speech skills improve the confidence, creativity, and competence among the students (Boonkit, 2010). In this way speaking ability can be enhanced. So the focus of the researchers is on the same notion. They consider the views of great critics about the importance of $\mathrm{A} / \mathrm{V}$ aids used in enhancing speaking skills of ESL learners. There are other reasons why AV aids has gained attraction in the classrooms of language learning. The role of AV aids is an authentic source of language proficiency (Coniam, 2001: Katchen, 2002.

Language is something we use. Language is a skill subject and the basis of language is practice. English is a foreign language for us but its importance can never be denied. Communication is an art. It is not important what we say, the most important is how we say and how we communicate with people. Teacher has great importance to make his students proficient in English speaking skill. A teacher can play a significant and positive role in this regard. So he should have command over spoken ability and possess a great deal of knowledge. The most active person in the room is the teacher. So it is the duty of the teacher to arrange more and more activities so that by using these activities, the students may get command over speaking skill (Anderson, 1985).

\subsection{ELT Situation in Pakistan}

In Pakistan, the role of English language is still under discussion. The western mind group favors it as medium of instructions. On the other hand, most of the Pakistanis are in favor of Urdu as medium of instructions. The students are familiar with English as it is being taught since class one to onward (Emerso, 2004). Elite class of the society uses English in communication. Any language uses four basic skills: listening, speaking, reading and writing. It is necessary to master these skills for better learning.

Effective communication depends on the systematic development of skills of language. The use of authentic materials and AV aids are helpful for development of language (Medly, 1987). Books and newspapers are of prime importance for language learning (Wekster, 2004).A.V. aids can be helpful for the teacher as well as provide a challenge to the learners to prepare themselves for real language interaction. We use A/V aids so that we can get command on speech because in language teaching speech has great importance. Speech is the most important aim in language teaching. A. V. aids play very important role in learning a language. A learner learns a language by hearing. So he must hear that language which is spoken often and well over a fairly lengthy period. Thus the more the pupil is exposed to good models and relevant material handled appears to him, the more likely he is to make considerable efforts to speak a language. Guidance is also given where appropriate on practical matters such as construction of aids. However, it must not be forgotten that their value depends on how much they contribute to the learning process.

Present study is an intention to check the importance of a/v aids in enhancing speaking skill of ESL learners. This study is beneficial for the students as well as for the teachers. It will investigate how the use of a/v aids helped ESL learners to overcome their short comings of speaking skill and motivate them to speak in the target language.

It is true that these A.V aids can be used to improve their speaking skill. For example text book is regarded as a form of visual aid where primary function is to reinforce what has been learnt orally. Ideally oral work should be carried out as far as possible. The teacher can also draw some sketches on the board. Drawing should be as simple as possible. Different kinds of A.V. aids can be used such as cartoon strips. Teacher can ask different kinds of questions from the learners by showing them interesting pictures of cartoons. In this way, they will take more interest in the activity because each has to give his own answer. 


\section{RESEARCH DESIGN AND METHODOLOGY}

Current study was experimental and the approach was quantitative. A questionnaire of 15 questions was prepared for the students about the importance of using A. V. aids in the classroom. The experiment lasted for three weeks (21) working days. ESL students were provided such classrooms where A. V. aids were used. Then they were observed. A checklist was prepared to check the progress and behavior of ESL learners.

\subsection{Population and Sample of the Study}

All the students enrolled in $10^{\text {th }}$ class in the year 2017 from Bahawalpur City were the population of the study. Fifty students were selected randomly from $10^{\text {th }}$ class.

\subsection{Research Tools}

\subsubsection{Questionnaire}

A close ended questionnaire was prepared for ESL teachers. Fifteen questions were included. The scale "level of agreement" was used to check the teachers' opinion about the importance of speaking skills through A. V. aids. This questionnaire was distributed among the teachers personally.

\subsubsection{Checklist}

A checklist was prepared to observe students during lectures. In these lectures, use of $A / V$ aids was the main thing. Different statements were written to check whether students take interest in speaking skills while using A.V aids. Their observations were taken by the researchers. They collected data with the help of this checklist and then discussed the result at the end.

\section{Data Analysis}

Ho1:There is no apparent distinction between ESL learners' performance in pre-test and posttest.

Table 1.Comparison between Pre-test and Post-test

\begin{tabular}{|l|l|c|c|c|c|c|}
\hline Group & Mean & N & Std. D. & t-value & p \\
\hline \multirow{2}{*}{} & Pretest & 30.56 & 50 & 6.952 & \multirow{2}{*}{.9831} & $.002^{* *}$ \\
\cline { 2 - 7 } & Posttest & 35.54 & 50 & 6.584 & & \\
\hline
\end{tabular}

${ }^{* *} p<0.01$

Paired sample t-test showed an apparent variance between the two groups. It was evident that post-test group performed better $(M=35.54, \mathrm{df}(49), p<.002$. The findings of the study proved that $A V$ aids had positive impact on ESL learners' speaking proficiency.

Ho2: There is no significant difference between AV aids usage and learners' satisfaction.

Table 2.Comparison between AV Aids Use and Learners' Satisfaction

\begin{tabular}{|l|c|c|c|c|c|}
\hline Variables & Mean & $\mathbf{N}$ & $\begin{array}{c}\text { Std. } \\
\text { Deviation }\end{array}$ & t-value & p \\
\hline $\begin{array}{l}\text { AVAids Use \& } \\
\text { Learners' Satisfaction }\end{array}$ & 3.21 & 50 & .98 & .676 & $.003^{* *}$ \\
\cline { 2 - 5 }
\end{tabular}

${ }^{* *} \mathrm{P}<0.01$

Paired sample t-test explored an apparent variance between the two groups. It was evident that use of AV Aids improves the learners' satisfaction $\mathrm{df}(49), p<0.01$. The findings of the study proved that $A V$ aids are helpful in learners' satisfaction of ESL learners' in speaking proficiency.

Ho3: There is no significant correlation between AV aids usage and learners' satisfaction.

Table 3.Correlation between AV Aids Use and Learners Satisfaction 
IJAEDU- International E-Journal of Advances in Education, Vol. V, Issue 13, April, 2019

\begin{tabular}{|l|c|c|c|}
\hline Indicators & $\mathbf{N}$ & Correlation & Sig. \\
\hline $\begin{array}{l}\text { AV Aids Use \& } \\
\text { Learners' Satisfaction }\end{array}$ & 50 & .805 & $.000^{* *}$ \\
\hline
\end{tabular}

${ }^{* *} \mathrm{p}<0.01$

There is a significant strong and positive correlation between the two variables. AV Aids Usage enhances the learners' satisfaction and improves their performance.

\subsection{Data Analysis of Students' Observation}

Students took much more interest in the activities full of $a / v$ aids. When they were provided some worksheets full of pictures, students' interest level grew. They participated in those activities actively and their confidence level also grew up. In the groups they spoke more in the target language. They were not shy but were trying to solve all the language riddles, described with the help of $a / v$ aids. They expressed their own ideas and in this manner their creativity also enhanced. They became part of the group and completed all the assigned targets. They were also full of motivation. Now all these points are described in the form of table and graph.

\begin{tabular}{|l|c|}
\hline Factors & $\%$ \\
\hline Take interest & 98 \\
\hline Participation & 100 \\
\hline Confident & 80 \\
\hline Motivation & 99 \\
\hline Speak in English & 98 \\
\hline
\end{tabular}

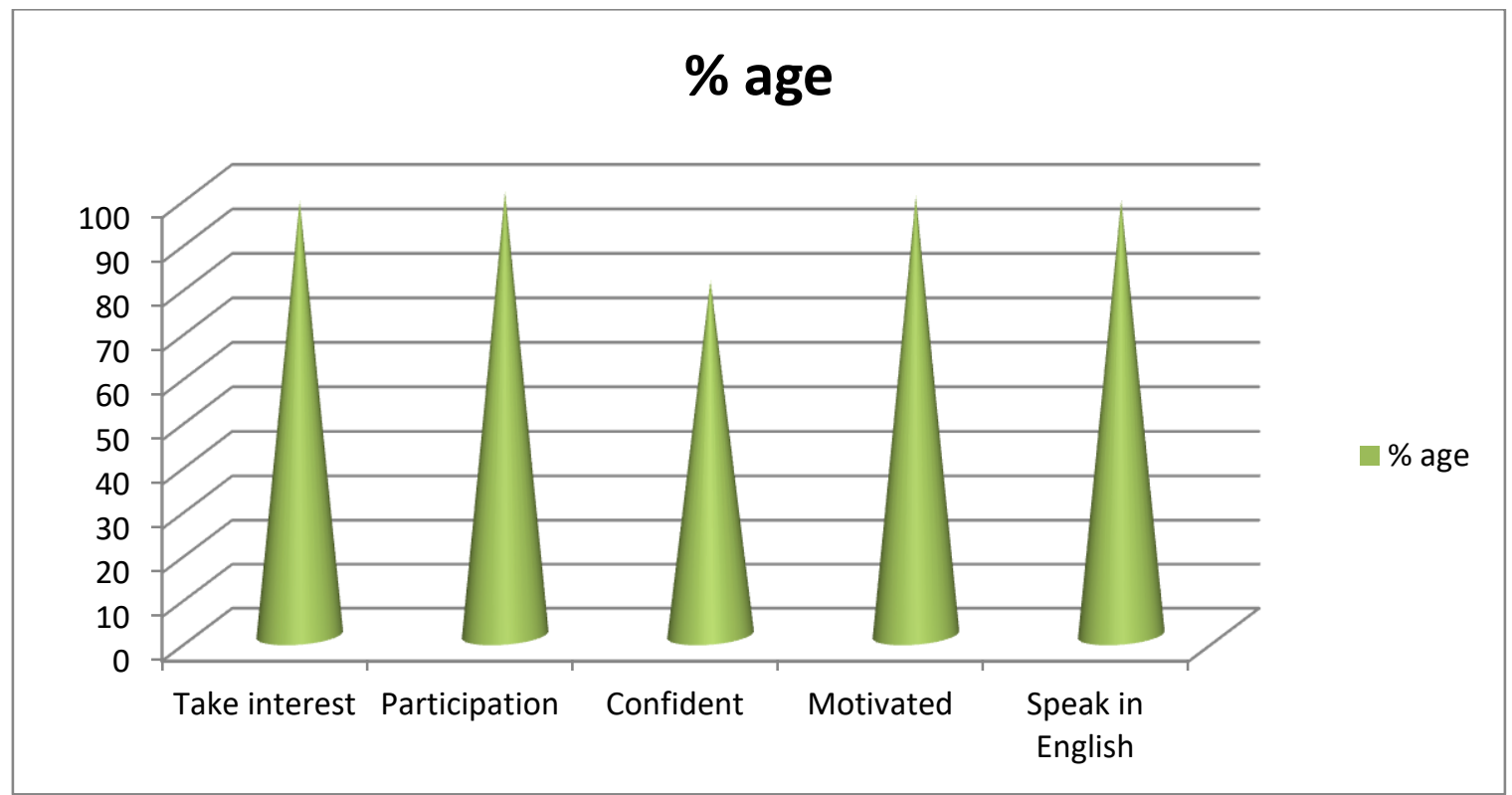

\subsection{Teachers Opinions about the Use of AV Aids}

A questionnaire used to check teachers' opinions about use of AV aids in their classes. Teachers admitted that students took more interest in target language learning with the help of AV aids. All the teachers were agreed 
IJAEDU- International E-Journal of Advances in Education, Vol. V, Issue 13, April, 2019

that use of $a / v$ aids enhances the motivational level of the students. The teacher told that students were more confident. They were agreed that use of $\mathrm{a} / \mathrm{v}$ aids had a positive impact on the minds of $\mathrm{ESL}$ learners.

\section{FINDINGS AND CONCLUSIONS}

The potential role of A.V aids needed to explore in speaking skills to assess whether it brings a positive change or not. It was noted that:

1. AV aids can be said as information, education and entertainment combined in one package.

2. AV aids are very good sources for teaching speaking skills because it increases student's ability to understand language outside the classroom context.

3. Its use motivates and encourages students to develop English speaking proficiency.

4. Change makes the productive progress in teaching techniques.

In a language classroom where students take admission for the sake of improving their English language but due to unavailability of lab equipment and experienced teachers they leave the institute. Recognized institutes, which really want to educate student, can be helpful. Honest, qualified teachers, lab equipment, suitable atmosphere, airy and bright classrooms, reasonable charges are useful for a language institutes as well as for school.

\subsection{Recommendations and Suggestions}

The experience and qualification of teachers had positive effect on students learning. They use more AV aids to improve the speaking proficiency of learners. It is suggested that AV aids material should be used properly. Activities are used to provide free and spontaneous practice of language with the help of $a / v$ aids.

\section{REFERENCE LIST}

Ameh, I. O. (2012). Motivating Use of Audio-visuals in a Nigerian Technological University Library. Journal of Educational and SocialResearch, 2 (1), 217-223.

Anderson, H. C. (1985). Techniques in language teaching. A division of Hodder and Stoughton. London Milburn Auckland.

Bailey, K.M. (2005). Practical English Language Teaching: Speaking. New York: McGraw-Hill.

Bal-Gezegin, B. (2014). An investigation of using video vs. audio for teaching vocabulary. Procedia - Social and Behavioral Sciences, 143, 450 - 457.

Boonkit, K. (2010). Enhancing the development of speaking skills for non-native speakers of English. Procedia Social and Behavioral Sciences, 2, 1305-1309.

Coniam, D. (2001). The use of audio or video comprehension as an assessment instrument in the certification of English language teachers: A case study. System, 29, 1-14.

Dalkılıç, N. (2013). The role of foreign language classroom anxiety in English speaking courses. Cukurova University Social Sciences Institute Magazine, (8), 70-82.

Ralph Waldo Emerson, Creating Positive Attitude towards

English as a foreign language, vol-44 no-4(2004)

2. Professor James, Second language teaching method,

principles and procedures. San Diegol State Unikerst

3. Noah Wekster (2004) Language and learning, (Third edition).

Australia. Oxford University Press

4. Hans Christens Anderson Techniques in language teaching 
Edward Arnold. A division of Hodder and Stoughton.

LONDON MILBURN AUCKLAND, 1985

5. Edward Thorndike, A course in language Teaching-Trance.

Book Cambridge university press, 1999

6. Medley, the practice of English language teaching Longman

printing press limited, 1987

7. Share and stanorish, A training course for TEFL. Oxford university press, 1983

8. Frier, teaching of English as a second language London Longman publishers

Ralph Waldo Emerson, Creating Positive Attitude towards

English as a foreign language, vol-44 no-4(2004)

2. Professor James, Second language teaching method, principles and procedures. San Diegol State Unikerst

3. Noah Wekster (2004) Language and learning, (Third edition).

Australia. Oxford University Press

4. Hans Christens Anderson Techniques in language teaching

Edward Arnold. A division of Hodder and Stoughton.

LONDON MILBURN AUCKLAND, 1985

5. Edward Thorndike, A course in language Teaching-Trance.

Book Cambridge university press, 1999

6. Medley, the practice of English language teaching Longman

printing press limited, 1987

7. Share and stanorish, A training course for TEFL. Oxford university press, 1983

8. Frier, teaching of English as a second language London Longman publishers

Ralph Waldo Emerson, Creating Positive Attitude towards

English as a foreign language, vol-44 no-4(2004)

2. Professor James, Second language teaching method, principles and procedures. San Diegol State Unikerst

3. Noah Wekster (2004) Language and learning, (Third edition).

Australia. Oxford University Press

4. Hans Christens Anderson Techniques in language teaching

Edward Arnold. A division of Hodder and Stoughton.

LONDON MILBURN AUCKLAND, 1985

5. Edward Thorndike, A course in language Teaching-Trance. 
Book Cambridge university press, 1999

6. Medley, the practice of English language teaching Longman

printing press limited, 1987

7. Share and stanorish, A training course for TEFL. Oxford university press, 1983

8. Frier, teaching of English as a second language London Longman publishers

Emerso, R.W. (2004). Creating Positive Attitude towards English as a foreign language, 44(4).

Goh, C. (2007). Teaching speaking in the language classroom. Singapore: SEAMEO Regional Language Centre.

Katchen, J. E. (2001). Using authentic video in English language teaching: Tips for Taiwan's teachers. Taipei:The Crane Publishing Company, Ltd Video in ELT-Theoretical and Pedagogical Foundations.

Ohata, K. (2005). Potential sources of anxiety for Japanese learners of English: Preliminary case interviews with five Japanese college students inthe US. TESL-EJ, 9(3), 1-21.

Osborn, S., Osborn, M., \& Osborn, R. (2008). Public speaking guidebook. Boston: Pearson.

Seçera, Y. E., Sahin, M., \& Alci, B. (2015). Investigating the effect of audio visual materials as warm-up activity in Aviation English courses on students' motivation and participation at high school level. Procedia - Social and Behavioral Sciences, 199, 120 - 128.

Songsiri, M. (2007). An action research study of promoting students' confidence in speaking English.

(Dissertation of Doctor of Education Degree), School of Arts, Education and Human Development, Victoria University, Australia.

Swank, R.C. (2011). The Educational Function of the University Library.

Thorndike, E. (1999). A course in language Teaching-Trance.Cambridge university press.

Wekster, N. (2004). Language and learning ( $3^{\text {rd }}$ ed.). Oxford University Press.

Woodrow, L. (2006). Anxiety and speaking English as a second language. SAGE Publications, 37(3), 308-328.

Wörde, R. (2003). Students' perspectives on foreign language anxiety. Inquiry, 8(1).

Zaremba, A. J. (2006). Speaking professionally. Canada: Thompson South-Western.

Zhang, Y. (2009). Reading to speak: Integrating oral communication skills. English Teaching Forum, 47(1), $32-$ 34. 